\title{
HOW THE GENE-EDITING IN MEDICINE AND PUBLIC HEALTH PRACTICE COULD STAND THE TEST OF BIOETHICS
}

\author{
Zheng Zang ${ }^{1}$, Yueqin Chen ${ }^{2}$
}

\begin{abstract}
In recent years, gene editing is increasingly used as one of the technical means to solve public health problems. The great progress made in the field of life science and gene-editing technology has made it possible for humans to control and alter human physiological characteristics through gene-editing technology and created a broad application prospect for this technology. However, gene-editing technology has faced with many significant ethical risks, and human gene editing experiments have been banned for a long time in the past. Realistic technological breakthroughs and the emergence of real cases force the ethics circle to re-examine this issue. Through the analysis and trade-off of the potential benefits and ethical risks of human gene-editing technology, it can be found that different applications of human gene editing for different purposes are considered to have different acceptability. Among them, human gene editing for medical purposes has no fundamental moral barriers, human gene editing for purposes of enhancement cannot be allowed by ethics and reality in the current social environment, and human gene editing for purposes of transformation fundamentally violates ethical norms. Therefore, gene editing can be allowed if it is only used to solve human medical and public health problems.
\end{abstract}

Keywords: gene-editing, public health, medical ethics, bioethics

De qué forma la tecnología de edición génica en medicina y salud pública puede ser aceptada al someterse a la reflexión bioética

Resumen: En años recientes, se usa cada vez más la edición génica como medio técnico para resolver problema de salud pública. El gran progreso realizado en el campo de las ciencias de la vida y la tecnología de edición génica ha hecho posible que el ser humano controle y altere las características fisiológicas humanas, usando esta tecnología y abriéndose una amplia perspectiva de aplicación. Sin embargo, esta tecnología enfrenta problemas éticos significativos, y los experimentos de edición génica en humanos han sido prohibidos por mucho tiempo en el pasado. Los avances tecnológicos realistas y la emergencia de casos reales ejerce presión sobre el círculo de reflexión ética para volver a examinar el tema. Mediante el análisis y balance de los potenciales beneficios y riesgos éticos de la tecnología de edición génica, se puede encontrar que las diferentes aplicaciones de ésta tecnología, para propósitos diferentes, tienen distinta aceptabilidad. Entre ellos, el uso de edición génica para propósitos médicos no tiene barreras morales fundamentales; la edición génica humana para propósitos de mejoramiento no debería permitirse en la realidad social actual, y la edición génica humana para propósitos de transformación viola fundamentalmente las normas éticas. Por lo tanto, la edición génica podría permitirse solamente para resolver problemas médicos y de salud pública en humanos.

Palabras clave: edición génica, salud pública, ética médica, bioética

Como a ediçáo de genes na prática médica e de saúde pública poderia apoiar o teste da bioética

Resumo: Em anos recentes, a edição de genes é cada vez mais usada como um recurso técnico para resolver problemas de saúde pública. O grande progresso feito no campo das ciências da vida e da tecnologia de edição de genes tornou possível para os humanos controlarem e alterarem as características fisiológicas humanas através da tecnologia da edição de genes e criou uma ampla perspectiva de aplicaçáo para esta tecnologia. Entretanto, a tecnologia de edição de genes enfrentou muitos riscos éticos significativos e os experimentos de ediçáo de genes humanos foram banidos por muito tempo no passado. Avanços tecnológicos realísticos e a emergência de casos reais forçaram o círculo ético a reexaminar esta questão. Através da análise e do equilíbrio entre os benefícios potenciais e riscos éticos da tecnologia de ediçáo de genes humanos, pode ser encontrado que diferentes aplicaçôes da edição de genes humanos para diferentes propósitos são consideradas ter diferentes aceitaçóes. Dentre elas, a edição de genes humanos com objetivos médicos não tem barreiras morais fundamentais, edição de genes humanos objetivando aprimoramento náo pode ser permitida pela ética e realidade do ambiente social atual, e edição de genes humanos objetivando transformaçáo fundamentalmente viola normas éticas. Portanto, ediçáo de genes pode ser permitida somente se usada para resolver problemas médicos humanos e de saúde pública.

Palavras chave: edição de genes. saúde pública, ética médica, bioética

\footnotetext{
${ }^{1}$ School of Philosophy, Zhongnan University of Economics and Law, Wuhan 400073, China. ORCID: https://orcid.org/00000001-5662-0741

Correspondence: zzhso@qq.com.

${ }^{2}$ School of Journalism and Culture Communication, Zhongnan University of Economics and Law, Wuhan 400073, China. ORCID: https://orcid.org/0000-0003-1556-7272

Correspondence: buhle@qq.com.
} 


\section{Introduction}

Human genetic gene-editing has been considered as an ethical forbidden zone in human science for a long time. The most basic ethical constraint on research involving humans is that it should not expose participants to unreasonable risk(1). Risks should be the minimum necessary to answer the scientific question, and the expected benefits should be proportionate to expected harms(2). While the Declaration of Helsinki states that research involving incompetent participants must be 'minimal risk and minimal burden(2 Paragraph 28). However, with the development of life sciences and the human desire for a better life, the further ethical discussion of human gene-editing technology has become much more urgent than ever before. Especially when people are faced with human medical and public health problems, whether gene editing as a promising technical means should be limited by medical ethics. This article will attempt to analyze the potential benefits and ethical risks of gene-editing technology and discuss the possible measures of dissolving the risk and ethical red lines that must be carefully treated. After weighing the advantages and disadvantages of both sides, it will point out which types of gene-editing technology can be accepted under what conditions. And under the background that people generally hold a cautious attitude towards gene editing, whether the gene editing used in the field of human medicine and public health can pass the test of medical ethics.

\section{Background}

With the continuous development of life sciences and biotechnology, human's understanding of gene is becoming increasingly deeper. More and more gene technologies have been put into practice in the real world, and these practices also offer the possibility of preventing, treating diseases and even changing biological characteristics by using gene-editing technology. At present, many human diseases, especially hereditary diseases, have been proved to be closely related to genes, and gene-editing technology has provided the chance of prevention and treatment for these previously insoluble hereditary diseases.

But the practical use of gene editing in human cells, especially in human embryos, is mainly off-limits. On the one hand, the gene-editing technology itself is not mature and stable enough, and there may be uncontrollable risks in the use of human embryos. On the other hand, there are many ethical controversies about gene editing in human embryos. As a result, the technique has always been banned like human cloning. In practice, the ban partly covers up the complexity of the ethical issues behind the technology. Because of the ban, many people simply take the immorality of human gene-editing technology as a conclusion without deep reflection.

Now, several incidents related to gene editing have forced people to face up to the ethical issues and application of this technology and make further reflection and discussion. In April 2015, Huang Jun, a Chinese researcher, published in the journal Protein and Cell that his team used CRISPR-Cas9 technology to modify the genes of human embryos(3). In 2016 and 2017, gene-editing experiments were carried out in Britain and the United States. In November 2018, Jiankui $\mathrm{He}$ announced the birth of the first pair of genetically edited babies. Although Dr. He's action has been deemed as a serious violation, it makes the birth of a genetically edited human a reality(4).

At the same time, the ethical discussion on human gene-editing technology has also developed accordingly. On February 15 in 2017, the Human Gene Editing Research Committee officially released a report on the science and technology, ethics and supervision of human gene editing to the world, which determined the "bottom line" of gene-editing technology for human use(5). In July 2018, a report by the Nuffield Council on Bioethics in the UK found that genetic gene editing could be morally permissible(6).

The potential benefits that gene-editing technology could bring to humans are clear. There is no doubt that the temptation for most of us to avoid genetic diseases, remedy genetic defects, or even gain the ability to excel is enormous. Advances in gene technology and Dr. He's illegal experiments have also made the practical application of gene editing a reality. It can not adapt to the development of the time that make a simple and general determination that it is of high risk and against 
ethics and release a ban on it in the past. Reality calls for a deeper analysis of the ethical issues behind gene editing in human embryos rather than evading them through ill-considered prohibitions.

\section{Analysis of the potential benefits}

This article will summarize the known potential advantages of human genetic gene editing techniques, analyze the ethical risks based on this, and discuss which techniques are acceptable and the prerequisites that must be complied with to accept these techniques. According to the purpose, human gene-editing technology can be divided into medical purpose and unmedical purpose. This article believes that medical and public health measures include the treatment of possible congenital diseases and prevention of possible acquired diseases treatment means; but unmedical measures include editing the gene to alter the human physical characteristic and enhance the human's innate ability.

\subsection{Gene editing for medical and public health purposes}

The application of human genetic gene editing for medical purposes is mainly to fight against various diseases, and its ultimate aim is to make people free from various diseases. This is consistent with the purpose of medical and public health development and the human's pursuit of increasing their own well-being. Medical and public health approaches can be further divided into active prevention and passive treatment.

Passive treatment refers to edit embryos to protect offspring from congenital diseases if they are known to carry disease-causing genes from their parents. For example, transfusion-dependent $\beta$ -thalassemia (TDT) and sickle cell disease (SCD) are severe monogenic diseases with severe and potentially life-threatening manifestations(7). George Daley, the Dean of Harvard Medical School, indicated that Huntington's disease or Tay-Sachs disease might be suitable targets for gene editing(8). In a society where genetic diseases and congenital diseases are widespread, it is an effective prevention and will undoubtedly effectively improve the quality of family life. At the same time, it is undoubtedly more humane to fundamentally avoid the possibility of contracting known congenital genetic diseases, compared with abortion of fetuses with severe congenital diseases through pregnancy test screening. This practice not only protects the fetuses, but also reduces the burden of their parents.

Active prevention refers to edit embryos to obtain the ability of protecting offspring from infecting acquired diseases. Dr. He's experiment is an example of active prevention aimed at preventing gene-edited babies from contracting AIDS thoroughly. If the technology is ideally applied, it would protect humanity from all kinds of acquired diseases, especially those which of no effective treatment currently, and improve human's wellbeing far more than passive treatment.

\subsection{Gene editing for unmedical purposes}

Gene editing for unmedical purposes mainly refers to gene editing for purposes in addition to treatment and prevention of diseases. It can be divided into forms of enhancement and modification. Modern life sciences and biotechnology has proved that many physiological characteristics of human beings are determined by genes, and by editing relevant genes, human physiological characteristics and corresponding abilities can be enhanced and transformed.

The difference between means of enhancement and modification mainly lies in whether the purpose is to pursue socially recognized advantages. Means of enhancement refers to the use of gene editing to obtain traits that most people in society recognize as advantageous, such as superior intelligence or physical strength. Means of modification pursues the parents' personal preferences or the characteristics recognized in a certain time and region, such as some skin color and hair color, facial features, etc.

The advantages of means of enhancement are predictable. If people's abilities in all aspects are effectively enhanced, human beings will be able to overcome physiological limits in a short time which are unbreakable in the past, and at the same time may break through the extremity of human civilization. Should the translatio- 
nal pathway extend to enhancing normal traits, such as intelligence? This has been the subject of almost 20 years of debate $(9,10)$. However, the potential social advantages of modification are uncertain, because the likes and dislikes of individuals or groups over time may not be equated with well-being of human.

In conclusion, of the four forms of gene editing divided by purposes of medical and unmedical purposes, except gene editing for modification, the other three, without considering other risks, can significantly improve well-being of human and possess huge potential advantages. Next, this article will discuss the ethical risks and possible ways to resolve them and try to explain under what conditions human beings can realize the potential advantages gene editing can bring.

\section{Analysis of ethical risks}

As well as the huge benefits that gene-editing technology may bring, it also has huge risks. Different from the general technical risks, human gene-editing technology at present is a fundamental change to human physiological characteristics, and its risks are very likely to be unbearable for human beings. At the same time, as a technology applied to humans themselves, the risks of human gene editing also have an ethical dimension(11). This article will discuss the risks of the application of this technology and whether there are possible paths of risk mitigation from three aspects of the technology itself, the users of the technology and the whole society.

In order to facilitate in-depth discussion of the risks at each level, this article assumes that there is no risk at other levels when we analyze the risks at any level, and finally considers the sum of the ethical risks at all levels.

\subsection{Medical risks of human gene-editing techno- logy itself}

The risks of medical technology should belong to the medical and public health field, but medical technology directly affects people, and medical development is closely related to human's wellbeing. Therefore, many medical risks actually have an ethical dimension that needs to be discus- sed at an ethical level. The risk is mainly divided into two categories: one is the immature technology itself may bring harm to the gene editors; The other is the risk that the specific nature of gene-editing technology can make damage spread across generations or even be incorporated into the human's gene pool.

For the first type of risk, some scholars believe that gene technology is not yet mature, and there may be unknown side effects or uncontrollable harm when we use the technology. Therefore, they believe that gene-editing technology is suspected of violating the principle of no harm and should not be used(3). But at this level, gene-editing technology, especially for medical purposes, does not have the particularity compared with other medical means, and the risk of its immature development can be analogized with the risk of other immature medical and public health means. It is therefore unsurprising that homozygosity for the CCR5 $\triangle 32$ variant has been shown to be significantly correlated with more symptomatic infection and higher mortality rates in patients with West Nile virus(12), influenza $A(13)$, and tickborne encephalitis(14). It has also been shown to be associated with upregulation of certain CC chemokine ligands, and in turn associated with progressive reduction in survival time for patients with multiple sclerosis (MS)(15). Is it ethical to create a sequence variation that confers resistance to one illness, while increasing the likelihood of succumbing to another(16)?

In modern society, the development of medicine cannot be separated from the development of medical and public health methods, which are always accompanied by huge risks. In the most nations, any new drug must undergo strict animal and human experiments before it is marketed, including volunteer experiments. In order to ensure that the majority of people use safe and effective new drugs, it has been widely accepted in reality that volunteers in drug trials suffer certain injuries due to drug trials.

Almost all new drugs cannot be developed if the principle of "no harm" is upheld, and modern medicine has been built on countless failures and sacrifices. Therefore, gene-editing technology cannot be arbitrarily banned on the principle of 
no harm. This does not mean that the technology can be developed without the principle, but should be subject to the same strict rules of risk control as any other medical procedure. In addition, due to the particularity of this technology itself, such as the use of human embryos of ethical risk in the experiment of this technology and the experiment of this technology may bring extremely serious harm to people. Risk controls for the development of gene-editing technology should be tightened, and its research should be halted if there is clear evidence of unmanageable harm.

The other type of risk is more serious than the first type which results in only personal harm. Genetic editing can be passed on from generation to generation, and injuries that are limited to individuals are more likely to be passed on to offspring through reproduction, even add defective genes to the human gene pool. The ethical issues raised by this risk go far beyond violating the principle of no harm, concerning the moral standing of those who are gene-edited and people's responsibilities to future generations.

For the person who accepts the gene editing, it is completely impossible for him to edit the gene out of his free will. Because he or she was only an embryo when he or she was edited, and he or she was born just like the other people and ought to deserve the same moral status. However, once the serious side effects of gene editing are found, it becomes a serious ethical dilemma whether to allow them to have offspring. If they are forbidden to pass on their genes, it is a violation of the basic dignity of human beings. But if the offspring are allowed to be born, it will plant a genetic hazard for the entire human generation, which is not responsible for the health of all future generations. However, if a large number of editing defects are incorporated into the human gene pool, it will have a huge negative impact on the development of human society, and in extreme cases may even threaten the survival of the entire human species.

Therefore, this article believes that the risk of immaturity of human gene-editing technology itself can be controlled through risk prevention and control measures similar to those used in the innovation of modern medical and public health means. Because of its own particularity, this pre- vention and control must be stricter. At the same time, genetic editing may carry the risk of gene defects spreading to the entire human gene pool, which means that human gene editing is fundamentally different from other medical and public health technologies and must be treated with extreme caution.

The risk of the technology is expected to be reduced through further conservative research, while the strict regulatory system will also effectively control the spread of its risk. Therefore, this article believes that gene-editing technology for medical purposes is still foreseeable in the future. In the face of such risks, gene-editing technology for enhancement should be suspended temporarily, and its application for modification is not expected to be reasonable.

\subsection{Rights and dignity risks involved in human gene-editing technology}

The ethical risk for the users of gene-editing technology also exists in two aspects: The first, the technology has been suspected of destroying the dignity and sanctity of human life for a long time; The second, the use of the technology undermines the right of the gene-edited person to choose openly.

The first ethical risk skeptics are most strongly held by religious people, especially Christians, who see gene editing as a human attempt to play God and create a new human being. But this challenge appeals entirely to the holiness of life to the holiness of God, which makes the theory unpersuasive among non-religious groups. A nonreligious version has risen in response to the proper time and conditions, arguing that genes are a fated and natural factor in human life, a precondition for the past state of human existence and a guarantee of human dignity. Gene editing undermines the sanctity and dignity of human life.

This article believes that the doubts from religion are not universally convincing, and the practice of linking genes with the dignity and essence of human life has strong theoretical influence. We do not object that human life may have insurmountable boundaries of human science and technology, but I am afraid that there is not enough rea- 
son to equate genes with the essence which marks human's dignity. The understanding of genes in the life sciences is undoubtedly a breakthrough, and it has enabled us to understand the further factors that determine human's physiological characteristics. However, from the perspective of history, people's understanding of gene is only a periodical discovery, and there are still countless secrets to be explored in the field of life science. Gene is only a relatively deep layer that people can understand at present, just as when natural scientists discovered the secrets of the atom, they once thought they had uncovered the secrets of the nature of the world, regarded the atom as the source of the world, even brought about a revolution in the philosophical world view and made mechanical materialism in full bloom. But it soon became clear that atoms were not the smallest particles, and that our understanding of them was far from sufficient to reveal the nature of the world. The same is true of genes. It is acceptable to think that human life has inherent dignity, but it is obviously not reliable to base this inherent dignity on a stage of knowledge of life science. The author thinks that appealing to God for the dignity of life essence makes at least logical sense, while appealing to genes is obviously not equal. So there is no sound basis for the ethical risk that gene-editing technology undermines the dignity of life.

The second risk is that gene editing imposes an artificial limit on the lives of those edited, violating the right of future generations to an open future. As long ago as the 1980s, the European Parliament argued that people should safeguard their right to an open future by protecting their offspring's genetic material from interference(17). Meanwhile, Dena Davis, a scholar at Cleveland State University, argues that future generations have a right to keep their choices open until they are able to make them(3).

But the ethical risk of violating the right of future generations to an open future applies only partially to the issue of gene editing. First, even if the offspring's genes are not artificially edited, they are predetermined, and when the offspring grow up to be able to choose on their own, they cannot choose their own set genes. So, at this level, gene editing doesn't violate the rights of future genera- tions. But in nature, the genetic traits of offspring are relatively uncontrollable, and the edited genes can be engineered. If the offspring lose the possibility of having certain characteristics because of artificial limitation, it can indeed be considered as the violation of the right of the offspring to have an open future.

But this violation applies only to gene editing for purposes of modification, and gene editing for medical purposes and enhancement does not violate the right of future generations to open up their future. For medical purposes, we generally do not consider that future generations own the right to suffer from certain diseases, and the guarantee of their health does not naturally infringe upon the non-existent right to choose to be unhealthy. For example, a person with a certain talent has the right or freedom to waste that talent, but for a person who does not have that talent at all, it is undoubtedly absurd to think that he has the right to waste that talent. In the case of gene editing, it is not reasonable to assume that future generations have the right to give up something they do not possess.

To sum up, most ethical risks in terms of human dignity and the rights of future generations have no foundation. Gene editing for the purpose of modification alone will violate the rights of future generations to have an open future, while geneediting technology for other purposes may not violate ethics at this level.

\subsection{The risks of human gene editing challenging social justice}

Human gene editing used for positive medical purposes and purpose of enhancement will significantly improve people's innate abilities. However, if this editing is only enjoyed by a few people, it will cause social disruption and serious risks, harming social fairness and justice.

It is well known that providing a good environment for children has a huge effect on the development of outstanding talents, and class solidification has resulted in many countries. As the Matthew Effect continues to work across generations, the gap between the rich and the poor will widen rapidly, while at the same time, it will 
narrow the path for the underclass to rise. And that's just a matter of nurture.

As a new technology with great potential, the cost of gene editing is bound to be relatively high, which means that only a few wealthy families can enjoy commercial gene-editing technology. Once they use this technology to enhance the innate ability of their offspring, coupled with superior acquired conditions, will make human society appear completely differentiated. Those who are unable to do so will fall behind those who are genetically edited. At the same time, environment widens the gap even wider, so that people who edit their genes become a different and superior category than those who don't. This is obviously a serious violation of social norms of fairness and justice, if it is allowed to develop, which will make the society have no equality and justice at all.

But this is only a pessimistic view of the problem. Gene editing may also have optimistic prospects on this ethical level. Antibiotics were also very expensive and rare drugs when they were first invented. However, with the development of medical and public health technology and the improvement of the corresponding medical security system, the vast majority of people in the world can now enjoy cheap and effective antibiotics. The reality is that the rich don't have access to antibiotics to protect themselves from most bacterial infections, and the poor don't have access to antibiotics and become a distinct class from the rich.

The same may be true of gene editing, which for negative medical purposes only prevents offspring from developing known genetic diseases, hardly creating a "superhuman class". Gene editing for positive medical purposes can increase the ability of the edited to resist disease to some extent, but it does not enhance other innate abilities, and its effect on class differentiation is relatively limited. Only gene editing for enhancement would significantly increase the differences between people, causing an irreversible class split.

Therefore, gene editing for medical purposes can be considered to put into application under the premise that the technology is relatively mature, and the relevant system is basically perfect. Geneediting applications for positive purposes should give priority to social benefits, as most vaccines do today. Priority should be given to combating more harmful and widespread diseases within the community, rather than creating "virus-proof" bodies for a few people. This would basically eliminate the ethical risk of undermining fairness brought about by gene editing for medical and public health purposes. However, the risk of gene editing for enhancement is too high to guard fairness and justice, and it should be strictly prohibited before the qualitative breakthrough of human gene technology and related regulatory system is achieved.

\section{Conclusions}

This article discusses four kinds of human genetic editing for different purposes and their potential value, as well as three levels of ethical risks that these four kinds of editing need to face, and finds that some of them are not valid. Some ethical risks are likely to be resolved in the application of gene-editing technology for specific purposes, while the rest risks do not still exist relative to the application of gene-editing technology for specific purposes.

Among them, the ethical risk that gene-editing technology is suspected of endangering the dignity of human life is proved to be unfounded, and the risk that gene-editing technology infringes the right of the edited person to have an open future is only true in gene editing for the purpose of modification. The development of gene-editing technology and the improvement of relevant social systems will help to eliminate the uncontrollable risks brought by gene-editing technology itself and the ethical risks of undermining social fairness and justice brought by gene-editing technology for medical and public health purposes. When this risk is mitigated to a low enough level, gene-editing technology can be considered as an overall benefit to human's well-being by considering the potential benefits and ethical risks.

Therefore, this article believes that gene-editing technology for medical and public health purposes can be accepted for clinical application under the condition of sufficient development of geneediting technology and relatively perfect social security system come true in the future. Gene 
editing for positive purposes should pay special attention to social benefits. Gene editing for purpose of enhancement has great ethical risks and should be set as an ethical forbidden area for a long time. But the potential benefits are far greater than genetic editing for medical and public health purposes, and cannot be completely dismissed. The author believes that the application of geneediting technology for enhancement should be weighed again when the gene-editing technology has achieved great breakthroughs or the survival and development of human beings are faced with great crises. Gene editing for the purpose of modification not only violates the ethical standards, but also has insufficient potential benefits. At the same time, it also bears the same technical risks as gene editing for other purposes. After weighing, the disadvantages obviously outweigh the benefits, and it should be completely banned.

Last but not least, this article argues that for cutting-edge issues such as gene editing, theory should consciously go ahead of the actual technological development. Once the development of technology goes beyond theoretical discussion and institutional construction, the negative impact of technology will become uncontrollable.
Institutional prohibition is indeed an effective prevention of risks, but it cannot stop the further theoretical discussion and new system construction of related issues just because the actual prohibition becomes a fact. In addition, the technology considered in this article that may be ethically acceptable is only in the ideal state, and the current reality does not have the relevant conditions. So, the relevant practitioners must strictly abide by the current norms.

Author Contributions: Conceptualization, Y.C. and Z.Z.; methodology, Y.C.; formal analysis, Y.C.; resources, Z.Z.; writing — original draft preparation, Y.C.; writing - review and editing, Y.C. and Z.Z.; supervision, Z.Z.; project administration, Z.Z.; funding acquisition, Z.Z. All authors have read and agreed to the published version of the manuscript.

Funding: This research was funded by the Chinese Ministry of Education of Humanities and Social Science Project (grant number 19YJCZH235).

Conflicts of Interest: The authors declare no conflict of interest. 


\section{References}

1. Savulescu J, Hope T. Ethics of research. In Skorupski, J. (Ed.), The Routledge companion to ethics. Abingdon, UK: Routledge; 2010: 781-795.

2. World Medical Association. Declaration of Helsinki Ethical principles for medical research in-volving human subjects, Paragraphs 16 and 17. Journal of the American Medical Association 2013; 310: 2191-2194.

3. Luo H, Rui R. What are we allowed to do? —Reflective balance of human embryo gene editing. Ethical Research 2017; 2: 111-117.

4. Zhu Y, Chen G. Review of hot science and technology events in 2018. Science and Technology Review 2019; 37: $218-$ 228.

5. Zhu Y. Review of hot science and technology events in 2017. Science and Technology Review 2018; 36; $199-210$.

6. Li J. Gene editing and human reproduction: social ethics and legal regulation. Journal of Soochow University 2018; 5: $125-134$.

7. Frangoul H, Altshuler D, Cappellini MD, Chen Y, Domm J, et al. CRISPR-Cas9 Gene Editing for Sickle Cell Disease and $\triangle$-Thalassemia, The New England Journal of Medicine 2021; 384: 252-260.

8. Cyranoski D. CRISPR-baby scientist fails to satisfy critics. Nature 2018; 564: 13-14.

9. Kass L. Beyond therapy: Biotechnology and the pursuit of human improvement. The President's Council on Bioethics. Retrieved from https://bioethicsarchive.georgetown.edu/pcbe/background/kasspaper.html

10. Savulescu J, Bostrom N. Human enhancement. Oxford, UK: Oxford University Press; 2009.

11. Ye Tian, Xia Liu. Gene editing: between modesty and openness. Journal of Shenzhen University (Humanities and Social Sciences Edition) 2018; 35(4): 106-115.

12. Glass WG, McDermott DH, Lim JK, Lekhong S, Yu SF, Frank WA, et al. CCR5 deficiency increases risk of symptomatic West Nile virus infection. Journal of Experimental Medicine 2006; 203: 35-40.

13. Dawson TC, Beck MA, Kuziel WA, Henderson F, Maeda N. Contrasting effects of CCR5 and CCR2 deficiency in the pulmonary inflammatory response to influenza A virus. American Journal of Pathology 2000; 156: 1951-1959.

14. Kindberg E, Mickienè A, Ax C, Åkerlind B, Vene S, Lindquist L, et al. A deletion in the chemokine receptor 5 (CCR5) gene Is associated with tickborne encephalitis. Journal of Infectious Diseases 2008; 197: 266-269.

15. Gade-Andavolu R, Comings DE, MacMurray J, Rostamkhani M, Cheng LC, Tourtellotte WW, et al. Association of CCR5 $\triangle 32$ deletion with early death in multiple sclerosis. Genet Med 2004; 6: 126-131.

16. Rothschild J. Ethical considerations of gene editing and genetic selection. Journal of General and Family Medicine 2020; 21: 37-47.

17. Zhu Z. Against Perfection? - Moral and legal philosophical thinking on human gene editing. Journal of East China University of Political Science and Law 2018; 21: 72-84.

Received: April 16, 2021

Accepted: April 27, 2021 